\title{
Profil Epilepsi Anak dan Keberhasilan Pengobatannya di RSUD Dr. Soetomo Tahun 2013
}

\author{
Pravita Tri Andrianti, ${ }^{*}$ Prastiya Indra Gunawan, ${ }^{*}$ Faroek Hoesin ${ }^{* *}$ \\ *Departemen Ilmu Kesehatan Anak **Departemen Patologi Anatomi Fakultas Kedokteran Universitas Airlangga, Surabaya
}

Latar belakang. Epilepsi adalah satu dari tiga kelainan neurologis tersering yang ditemui di praktek pediatri. Insiden epilepsi di negara berkembang dua kali lebih banyak daripada negara industri.

Metode. Studi deskriptif retrospektif menggunakan rekam medis,variabel meliputi jumlah kasus baru, usia, jenis kelamin, riwayat keluarga, EEG, CT-scan, MRI dan keberhasilan terapi selama 2013 di RSUD Dr. Soetomo Surabaya.

Hasil. Terdapat 103 kasus baru epilepsi anak terbanyak usia 1-5 tahun (45,63\%), laki-laki (71,84\%), tanpa pengobatan sebelumnya (32,04\%), riwayat keluarga kejang/epilepsi (93,20\%), kelainan perinatal (83,50\%), maupun gangguan tumbuh kembang (63,11\%). Hasil EEG 72,84\% abnormal, 61,53\% CT-scan kepala normal dan 57,14\% MRI normal. Tipe bangkitan 55,34\% general. Obat yang diberikan adalah asam valproat $(89,32 \%)$ dan $75,73 \%$ kejang dapat terkontrol.

Kesimpulan. Terdapat 103 kasus baru epilepsi anak, terbanyak usia 1-5 tahun dan laki-laki. Hasil pemeriksaan EEG umumnya abnormal di lobus temporal, tetapi lebih dari separuh kasus memperlihatkan CT-scan kepala dan MRI normal. Asam valproat terbanyak digunakan mengontrol kejang. Sari Pediatri 2016;18(1):34-9

Kata kunci: epilepsi anak, kasus baru, profil, keberhasilan terapi

\section{Profile of Epilepsy in Children and its Treatment Results in Dr. Soetomo General Hospital}

Pravita Tri Andrianti, ${ }^{*}$ Prastiya Indra Gunawan, ${ }^{*}$ Faroek Hoesin ${ }^{* *}$

Background. Epilepsy is one of the three most common neurologic disorders seen in a pediatric practice setting. Incidence of epilepsy in developing country is two times higher than in industrial country but very few studies done on new epilepsy cases and its profile among children in some countries.

Method. This is a retrospective study based upon medical records data, that were analyzed descriptively which include the total number of new cases, their age, gender, and history of children with epilepsy, their EEG, CT-Scan, MRI results and also the treatment outcome during the year of 2013 in Dr. Soetomo General Hospital, Surabaya.

Result. There were 103 new cases of children with epilepsy. The number of cases were high in 1-5 years age group (45,63\%), more common in male $(71,84 \%)$, without any prior medication $(32,04 \%)$, without family history of epilepsy or convulsion $(93,20 \%)$, without abnormality during delivery $(83,50 \%)$, and with no history of developmental delay $(63,11 \%)$. The results of EEG was abnormal in $72,84 \%$ but $61,53 \%$ patients show normal results of CT-scan and $57,14 \%$ had normal MRI test results. The type of seizure was $55,34 \%$ had generalized. The most common therapy given was monotherapy: valproic acid (89,32\%) and 75,73\% patient's had their seizure controlled.

Conclusion. There were 103 new cases of epilepsy in children, with most common among 1-5 years age group and male. EEG commonly abnormal, but CT scan and MRI results mostly normal. Valproic acid was most common given therapy and resulting its ability to control most patients seizure. Sari Pediatri 2016;18(1):34-9

Keyword: epilepsy in children, new cases, profile, therapy result

Alamat korespondensi: Dr. Pravita Tri Andrianti, Fakultas Kedokteran Universitas Airlangga, Jl. Mayjend Prof. Dr. Moestopo 47 Surabaya, E-mail: pravita.andrianti8@yahoo.com 
$\mathrm{E}$ pilepsi adalah satu dari tiga kelainan neurologis tersering ditemui di praktek pediatri. ${ }^{1}$ Kejadian epilepsi tergolong masih cukup tinggi. Insiden epilepsi diperkirakan lebih banyak di negara berkembang daripada negara industri. ${ }^{2}$ Di Indonesia kasus epilepsi berjumlah paling sedikit 700.000-1.400.000 kasus dengan pertambahan 70.000 kasus baru setiap tahun dan diperkirakan sekitar 40\%-50\% dari prevalensi tersebut terjadi pada anak-anak. ${ }^{3}$ Pengobatan epilepsi sebaiknya dimulai dengan satu macam obat. Idealnya, pemilihan jenis obat tergantung pada tipe epilepsi dan tipe serangan atau bangkitan (seizure). Oleh karena pada awalnya sangat sulit untuk menentukan tipe epilepsi maka terapi dimulai menurut tipe bangkitan. ${ }^{4}$ Selanjutnya, pengobatan sebaiknya diikuti dengan follow up pengobatan yang seharusnya diberikan setiap hari. Pengobatan diberikan untuk beberapa tahun, kadang-kadang seumur hidup, atau lebih singkat. $^{5}$

Tujuan studi ini untuk mengetahui profil epilepsi pada anak dan keberhasilan pengobatannya di RSUD Dr. Soetomo Surabaya selama tahun 2013. Penelitian ini diharapkan dapat memberikan informasi untuk digunakan sebagai data acuan serta meningkatkan pelayanan dan pengobatan sehingga dapat menurunkan jumlah kasus epilepsi pada anak.

\section{Metode}

Jenis penelitian deskriptif dilakukan pada retrospektif populasi semua pasien baru epilepsi anak yang berobat di URJ Kesehatan Anak RSUD Dr. Soetomo Surabaya. Subjek penelitian adalah semua pasien baru epilepsi anak yang berobat pada periode Januari 2013-Desember 2013 yang memiliki rekam medik. Pengambilan sampel digunakan consecutive sampling, dan memenuhi kriteria dalam jangka waktu yang telah ditentukan. Variabel yang diteliti adalah usia, jenis kelamin, riwayat pengobatan, riwayat penyakit dalam keluarga, kelainan perinatal, gangguan tumbuh kembang, hasil elektroensefalografi (EEG), CT-scan kepala, dan magnetic resonance imaging (MRI) kepala serta pengobatan yang diberikan. Metode yang digunakan adalah pencatatan data pasien dari basis data rekam medik. Data yang didapatkan kemudian dijabarkan secara deskriptif dalam bentuk tabel.

\section{Hasil}

Selama periode Januari 2013- Desember 2013, jumlah kasus baru epilepsi anak di RSUD Dr. Soetomo Surabaya 103 kasus. Kasus terbanyak terjadi pada usia pasien 1-5 tahun $(45,63 \%)$ dan jenis kelamin lakilaki $(71,84 \%)$ tertera pada Tabel 1 . Pada penelusuran riwayat pasien didapatkan $68 \%$ pasien tidak pernah berobat kejang sebelumnya, 93,2\% tidak memiliki riwayat keluarga kejang ataupun epilepsi, 83,5\% tidak mengalami kelainan perinatal, dan $63,1 \%$ tidak mengalami gangguan tumbuh kembang (Tabel 2).

Dalam menentukan diagnosis epilepsi dilakukan beberapa pemeriksaan penunjang, antara lain, EEG, CT scan, dan MRI. Di antara 103 pasien, 81 dilakukan pemeriksaan EEG dengan hasil 72,8\% abnormal dan ketidaknormalan tersebut paling banyak di lobus temporal (22,2\%). Pemeriksaan CT scan kepala hanya dilakukan pada 13 pasien dengan hasil 61,5\% normal. Pemeriksaan MRI kepala dilakukan pada sebagian

Tabel 1 Karakteristik umum pasien epilepsi anak

\begin{tabular}{lc}
\hline Variabel & $\mathrm{N}(\%)$ \\
\hline Usia (tahun) & \\
$<1$ & $22(21,4)$ \\
$1-5$ & $47(45,6)$ \\
$6-10$ & $25(24,3)$ \\
$11-15$ & $9(8,7)$ \\
Jenis kelamin & \\
Laki-laki & $74(71,8)$ \\
Perempuan & $29(28,2)$ \\
\hline
\end{tabular}

Tabel 2. Riwayat pasien epilepsi anak

\begin{tabular}{lc}
\hline Riwayat & $\mathrm{N}(\%)$ \\
\hline Riwayat pengobatan sebelumnya & \\
$\quad$ Pernah & $33(32)$ \\
$\quad$ Belum pernah & $70(68)$ \\
Riwayat epilepsi/kejang keluarga & \\
$\quad$ Ada & $7(6,8)$ \\
$\quad$ Tidak ada & $96(93,2)$ \\
Kelaianan perinatal & \\
$\quad$ Ada & $17(16,5)$ \\
$\quad$ Tidak ada & $86(83,5)$ \\
Gangguan tumbuh kembang & \\
$\quad$ Ada & \\
$\quad$ Tidak ada & $38(36,9)$ \\
& $65(63,1)$
\end{tabular}


kecil pasien, yaitu 7 dengan hasil 4 pasien normal. Hal tersebut tertera pada Tabel 3.

Tipe kejang dari pasien paling banyak adalah general, yaitu 55,3\%, sedangkan fokal 37,9\% dan sisanya tidak spesifik. Pengobatan yang banyak diberikan adalah asam valproat $(89,3 \%)$ dengan tingkat keberhasilan terapi yang diamati selama 6 bulan pertama sebesar 75,7\% (Tabel 4).

Tabel 3. Hasil pemeriksaan penunjang pasien epilepsi anak

\begin{tabular}{lc}
\hline Hasil pemeriksaan & $\mathrm{N}(\%)$ \\
\hline EEG $(\mathrm{n}=81)$ & $22(27,2)$ \\
Normal & \\
Abnormal & $18(22,2)$ \\
Temporal & $9(11,1)$ \\
Temporal bilateral & $3(3,7)$ \\
Prefrontal & $1(1,2)$ \\
Frontal & $1(1,2)$ \\
Frontal bilateral & $7(8,6)$ \\
Frontotemporal & $6(7,1)$ \\
Centrotemporal & $3(3,7)$ \\
Temporoparietal & $1(1,2)$ \\
Hemisfer & $3(3,7)$ \\
Multiregional & $7(8,6)$ \\
General & \\
CT-scan $(\mathrm{n}=13)$ & $8(61,5)$ \\
Normal & $5(38,4)$ \\
Abnormal & \\
MRI (n=7) & $4(57,1)$ \\
Normal & $3(42,9)$ \\
Abnormal &
\end{tabular}

Tabel 4. Tipe kejang dan hasil pengobatan pasien epilepsi anak

\begin{tabular}{lc}
\hline Variabel & $\mathrm{N}(\%)$ \\
\hline Tipe kejang & \\
General & $57(55,3)$ \\
Fokal & $39(37,9)$ \\
Tidak spesifik & $7(6,8)$ \\
Pengobatan & \\
Asam valproat & $92(89,3)$ \\
Phenitoin & $1(1)$ \\
Phenobarbital & $5(4,9)$ \\
Carbamazepine & $1(1)$ \\
Asam Valproat + phenitoin & $2(1,9)$ \\
Asam Valproat + carbamazepine & $1(1)$ \\
Phenitoin + carbamazepine & $1(1)$ \\
Keberhasilan terapi & \\
Terkontrol & $78(75,7)$ \\
Tidak terkontrol & $25(24,3)$ \\
\hline
\end{tabular}

\section{Pembahasan}

Kasus baru epilepsi anak di Unit Rawat Jalan (URJ) RSUD Dr. Soetomo Surabaya, pada tahun 2013 tercatat 103 pasien baru. Menurut penelitian di RSUP Sanglah Denpasar, rerata kasus per tahun 69 pasien, di RSAB Harapan Kita rerata per tahun 64 kasus. ${ }^{6,7}$ Terdapat perbedaan jumlah kasus disebabkan jumlah pasien yang ditangani RSUD Dr. Soetomo, sebagai rumah sakit rujukan Indonesia Timur, lebih banyak sehingga jumlah kasus baru terlihat lebih banyak. Kelompok umur terbanyak mengalami epilepsi adalah usia 1-5 tahun sesuai dengan penelitian Suwarba $(42 \%){ }^{6}$

Benarjee dan Hauser ${ }^{2}$ melaporkan bahwa kejadian epilepsi tetap pada kelompok usia termuda, dengan insiden tertinggi pada beberapa bulan pertama kehidupan. Insiden turun setelah setahun pertama kehidupan dan akan menetap selama sepuluh tahun pertama. Kami mendapatkan hasil usia yang berbeda karena populasi yang digunakan adalah kasus rumah sakit bukan populasi komunitas. Jumlah kasus lakilaki $(71,8 \%)$ didapatkan lebih banyak daripada perempuan. Hal tersebut sesuai dengan penelitian Suwarba yang melaporkan persentase pasien baru anak laki-laki 56,9\%, sementara Putri $^{8}$ di RSUP Fatmawati melaporkan 51,3\%, dan Tjandrajani ${ }^{6}$ di RSAB Harapan Kita, Jakarta, melaporkan 53,9\%. Pada kebanyakan studi populasi, insiden epilepsi didapatkan lebih banyak pada laki-laki dibanding perempuan. ${ }^{2}$ Asadi dan Hojabri' melaporkan bahwa laki-laki dapat menjadi faktor risiko pada epilepsi. Hal tersebut belum dapat dijelaskan dengan pasti mengapa laki-laki dapat menjadi faktor risiko terjadinya epilepsi.

Pada penelitian kami, 34\% pasien telah mendapat terapi obat kejang sebelumnya. Riwayat obat yang sering digunakan adalah monoterapi asam valproat. Hal tersebut sesuai dengan teori bahwa pengobatan epilepsi dimulai dengan satu macam obat saja. Pilihan asam valproat yang digunakan untuk berbagai tipe bangkitan kejang karena umumnya terapi awal pasien sebelum masuk RSUD Dr. Soetomo belum diketahui pasti.

Pada 93,2\% kasus baru tidak dimiliki riwayat keluarga epilepsi ataupun kejang sebelumnya, sama dengan laporan Suwarba dengan $87 \% .{ }^{6}$ Riwayat dalam keluarga meningkatkan risiko terjadinya epilepsi 4,75 kali dalam laporan Cansu $\mathrm{dkk}^{10}$ dan 3,34 kali dalam laporan Asadi dan Hojabri. ${ }^{9}$ Riwayat epilepsi/kejang 
pada keluarga hanya sebagai faktor risiko bukan penyebab langsung terjadinya epilepsi. Kelainan perinatal dialami $16,5 \%$ pasien, seperti bayi biru, tidak langsung menangis, tidak bernafas spontan, dan bayi lahir kuning, serta ada beberapa kelainan pada ketuban ibu. Berbagai kelainan perinatal dapat menjadi faktor risiko terjadinya epilepsi pada anak.

Cansu dkk ${ }^{10}$ melaporkan bahwa skor Apgar yang rendah meningkatkan risiko epilepsi. Laporan lain menyatakan asfiksia atau respiratory distress syndrome dan nilai Apgar yang rendah menjadi faktor risikonya. Beberapa studi yang melaporkan ikterus pada neonatus ada hubungannya dengan epilepsi pada anak. Cansu dkk melaporkan bahwa dari univariate analysis, neonatal jaundice meningkatkan risiko epilepsi 3,12 kali. Didapatkan 63,1\% kasus tidak mengalami gangguan tumbuh kembang, sisanya mengalami beberapa kelainan tumbuh kembang, antara lain belum dapat bicara, duduk sendiri, berdiri atau dengan jalan yang masih menyeret dan sering terjatuh, serta palsi serebral. Suwarba juga melaporkan bahwa sebagian besar $(75 \%)$ tumbuh kembang anak dengan epilepsi normal. ${ }^{6}$ Kejang pada epilepsi yang tidak terkontrol dapat menjadi penyebab kerusakan neuron di otak sehingga akan menyebabkan gangguan pada proses tumbuh kembang anak. ${ }^{11}$

Di antara 81 pasien, hasil EEG abnormal 59 $(72,8 \%)$, serupa dengan penelitian Tjandrajani ${ }^{7}$ yang melaporkan $82,3 \%$ tidak normal. Hampir selalu terlihat sinyal abnormal di EEG selama serangan epilepsi. ${ }^{12}$ Namun, pada penelitian kami, sebagian $(27,2 \%)$ hasil EEG normal. Bagaimanapun, EEG yang normal tidak mengesampingkan adanya epilepsi. Interpretasi EEG dapat dipercaya hanya jika direkam dengan baik dan diinterpretasikan oleh ahli yang telah berpengalaman dengan sedikitnya pelatihan selama setahun. Rekaman EEG 3-4 hari setelah serangan epilepsi (seizure) yang terakhir untuk menghindari gangguan interpretasi akibat keadaan post-ictal. Prosedur aktivasi minimum, seperti hiperventilasi dan stimulasi cahaya seharusnya digunakan sebab abnormalitas epilepsi biasanya dapat ditimbulkan oleh kedua hal ini. Pengurangan jam tidur juga dapat dilakukan sebagai aktivasi sebelum pemeriksaan EEG. Penghentian penggunaan anti-epileptic drug (AED) saat perekaman tidak direkomendasikan. ${ }^{13}$ Hasil EEG yang tidak normal terbanyak berada di lobus temporal. Sesuai dengan hasil telaah Zenteno dan Ronquillo ${ }^{14}$ bahwa pada kasus epilepsi yang dirujuk ke rumah sakit paling banyak ditemukan kelainan di lobus temporal.

Pada penelitian kami, 12,6\% pasien baru anak dengan epilepsi yang dilakukan pemeriksaan $C T$ -scan kepala, sebagian besar kasus normal (61,53\%). Sementara hasil CT -scan tidak normal, antara lain brain atrophy, subdural effusion, asymetical brain parencym dengan ventrikulomegali lateral kiri, encephalomacia cyst, serta adanya massa solid kistik dan peningkatan tekanan intrakranial. Dalam hal ini Suwarba melaporkan 51,3\% kasus abnormal. ${ }^{6}$ Perbedaan tersebut karena jumlah pasien yang dilakukan pemeriksaan $C T$ scan dalam penelitian kami lebih sedikit dibandingkan penelitian Suwarba yang mencapai $40 \%$ pasien.

Penelitian lain melaporkan bahwa pada anak epilepsi ditemukan hasil CT scan kepala abnormal pada 7\%-24\% kasus. ${ }^{15}$ Kami mendapatkan 7 dari 103 pasien baru anak dengan epilepsi yang dilakukan pemeriksaan MRI. Hasil pemeriksaan MRI didapatkan 42,9\% abnormal. Hasil MRI yang tidak normal, antara lain atrophy and sclerotic hypocampus serta brain atrophy pada frontoparietal. Pada pasien yang didiagnosis epilepsi, sekitar 12\%-14\% terlihat adanya lesi penyebab pada pemeriksaan MRI. Sekitar $80 \%$ pasien dengan serangan berulang memperlihatkan adanya abnormalitas pada pemeriksaan MRI. ${ }^{12}$ Pada penelitian kami, hasil MRI lebih banyak abnormal dan karena jumlah pasien diperiksa MRI hanya sedikit $(6,8 \%)$ maka tidak dapat mewakili sampel keseluruhan.

Dari revisi klasifikasi menurut ILAE pada tahun 2010, tipe kejang dapat dikelompokkan menjadi serangan umum (generalized seizure), serangan fokal (focal seizure) serta serangan yang tidak diketahui (unknown). ${ }^{16}$ Kami menemukan 55,3\% generalized seizure, 37,9\% focal seizure, dan 6,8\% unknown. Suwarba juga melaporkan hasil serupa dengan tipe generalized $80,4 \%$, sementara Tjandrajani melaporkan $78,6 \%$ generalized seizure. ${ }^{6,7}$ Menurut Banerjee dan Hauser ${ }^{2}$ yang menelaah beberapa penelitian di beberapa negara, tipe generalized seizure adalah yang paling sering ditemui pada studi populasi.

Pengobatan pasien epilepsi dengan anti-epileptic drug (AED), bertujuan untuk pencegahan bangkitan selanjutnya, baik secara keseluruhan ataupun mengurangi frekuensi dan tingkat keparahan dengan sedikit mungkin efek samping yang ditimbulkan. Pengobatan sebaiknya dimulai dengan satu macam obat. Idealnya, pemilihan jenis obat tergantung 
pada tipe epilepsi dan tipe serangan atau bangkitan (seizure). ${ }^{4}$ Kami mendapatkan 96,1\% menggunakan monoterapi. Obat terbanyak digunakan adalah asam valproat $(89,3 \%)$. Obat epilepsi yang digunakan merupakan obat pilihan pertama. Asam valproat banyak digunakan karena tingkat keberhasilannya lebih tinggi sebagai monoterapi $(64,7 \%)$. Pemakaian fenitoin dan fenobarbital dalam monoterapi terlihat hampir sama antara gagal dan berhasilnya monoterapi. Bahkan, pemakaian carbamazepine lebih banyak gagal dalam monoterapi epilepsi anak. ${ }^{17}$ Selain digunakan karena tingkat keberhasilannya yang tinggi, asam valproat juga efektif pada semua tipe kejang, terutama tipe absans.

Asam valproat dapat digunakan baik pada tipe generalized maupun focal-partial seizure. ${ }^{18}$ Fenitoin juga merupakan obat anti kejang yang efektif untuk parsial dan GTCS, serta bangkitan (seizure) selama tidur. Masalah utama adalah batas terendah antara kadar terapi dengan kenaikan kadar dalam serum yang dapat menyebabkan toksisitas obat tersebut. ${ }^{19}$

Obat lain seperti barbiturat dan golongan benzodiazepine yang merupakan obat sedatif, terdapat kecenderungan untuk dibatasi penggunaannya. ${ }^{18} \mathrm{Kami}$ mendapatkan keberhasilan terapi 6 bulan pertama 75,7\% pasien baru epilepsi anak dapat terkontrol. Penelitian lain melaporkan dalam 6 bulan pertama pengobatan, epilepsi dengan kejang $\geq 3$ kali ditemukan $31,1 \%$ remisi. Sementara itu, dalam 6 bulan kedua pengobatan, epilepsi dengan kejang sama atau lebih dari 3 kali didapatkan 18,9\% remisi. Keberhasilan terapi pada pasien epilepsi dipengaruhi oleh berbagai faktor. Menurut Triono, ${ }^{17}$ faktor yang berhubungan dengan keberhasilan atau kegagalan terapi pasien epilepsi, antara lain, frekuensi kejang sebelum terapi $>10$ kali, status epileptikus, terdapat defisit neurologis, kelainan neurologis penyerta, dan pemberian obat antiepilepsi yang terlambat. Pada penelitian kami, kelima faktor tersebut sangat minimal sehingga keberhasilan terapi yang dicapai cukup tinggi.

\section{Kesimpulan}

Terdapat 103 kasus baru epilepsi anak, terutama pada laki-laki usia 1-5 tahun. Hasil pemeriksaan EEG umumnya abnormal di lobus temporal, tetapi $C T$ scan dan MRI normal. Asam valproat terbanyak digunakan dan kejang dapat terkontrol.

\section{Daftar pustaka}

1. Steven MW, Patricia E M. Recognition and management of pediatric seizures. Pediatric Annals [online] 2006, 35 : 5[Diunduh pada 25 April 2014]. Didapat dari : http://www.wehealny.org/services/bi_pedsepilepsycenter/ peds\%20annals\%20article.pdf

2. Poonam N B,W Allen H. Dalam: Jerome Engel JR, Timothy A. Pedley, penyunting. Epilepsy: a comprehensive textbook. Edisi kedua. Philadelphia : Lippincott Williams \& Wilkins 2007.h.45-56.

3. Harsono, Endang K, Suryani G. Pedoman tata laksana epilepsi. Edisi Ke-3. Perdossi 2006;62:1-43.

4. Tracy G, Elinor B-M, Blaise B dkk. ILAE treatment guidelines: evidence-based analysis of antiepileptic drug efficacy and effectiveness as initial monotherapy for epileptic seizures and syndrome. Epilepsia 2006;47 :1094-120.

5. Marson A, Jacoby A, Johnson A, Kim L, Gamble C, Chadwick D. Immediate versus deferred antiepileptic drug treatment for early epilepsy and single seizures: a randomised controlled trial. Lancet [online] 2005, 365:2007-13 [Diunduh pada 25 April 2014]. Didapat dari : http://www.ncbi.nlm.nih.gov/pubmed/15950714.

6. Suwarba IGN Made. Insiden dan karakter klinis epilepsi pada anak. Sari Pediatri 2011;13:123-7.

7. Tjandrajani A. Karakteristik kasus epilepsi di Rumah Sakit Anak dan Bunda Harapan Kita pada tahun 20082010. Sari Pediatri 2012;14:143-6.

8. Putri M A. Prevalensi epilepsi di Poliklinik Saraf RSUP Fatmawati Jakarta pada tahun 2004-2008, skripsi. Jakarta:, Universitas Islam Negeri Syarif Hidayatullah Jakarta, 2009.

9. Asadi-Pooya AA \& Hojabri K. Risk factors for childhood epilepsy: a case-control study. Epilepsy Behav 2005;6:203-6.

10. Ali C, Ays se Serdarog `lu, Deniz Y, dkk. Prevalence of some risk factors in childhood with epilepsy compared to their controls. Seizure 2007;16:338-44

11. Wibowo AR, Saputra DR. Prevalens dan profil klinis pada anak palsi serebral spastik dengan epilepsi. Sari Pediatri 2012;14:1-7.

12. John PL, Rebecca O. Epilepsy simplified. London: TFM Publishing; 2007.

13. Neeta N. Guidelines for diagnosis and management of childhood epilepsy. Indian Pediatr 2009;46:681-98

14. Jose F, T'ellez Z, Lizbeth H R. A review of the epidemiology of temporal lobe epilepsy. Epilepsy Res Treat J [online] Volume 2012 [Diunduh pada 19 Agustus 
2015]. Didapat dari : http://www.hindawi.com/journals/ ert/2012/630853/.

15. William D. Gaillard, Catherine C, Helen C. Guidelines for imaging infants and children with recent-onset epilepsy. Epilepsia [online] 2009;50:2147-53.

16. Anne TB, Samuel FB, Martin JB, dkk. Revised terminology and concepts for organization of seizures and epilepsies: report of the ILAE commission on classification and terminology, 2005-2009. Epilepsia
2010;51:676-85.

17. Triono A, Herini E. Faktor prognostik kegagalan terapi epilepsi pada anak dengan monoterapi. Sari Pediatri 2014;16:248-53.

18. Katzung, Bertram G, Masters, Susan B, Trevor, Anthony J. Basic and clinical pharmacology. Edisi ke-12. McGraw Hill Medical; 2012.

19. Marla JF, Sharieff GQ. Seizures in children. Pediatr Clin N Am 2006;53:257-77. 